\title{
Transition From Low-Threshold Vocational Education and Training to Work in Switzerland: Factors Influencing Objective and Subjective Career Success
}

\author{
Claudia Hofmann*, Xenia Müller, Annette Krauss, Kurt Häfeli \\ University of Applied Science in Special Needs Education, Schaffhauserstr. 239, \\ 8050 Zurich, Switzerland
}

Received: 03 July 2020, Accepted: 15 March 2021

\begin{abstract}
Context: There are currently two low-threshold vocational education and training (VET) options in Switzerland for young people at risk: A two-year programme for a Federal VET certificate and a practical training programme designed for young people with special needs. In the present study, we looked at transitions from these programmes to the labour market. Possible influences on objective and subjective indicators of career success, such as social background, personal disposition, and training, were considered.

Methods: Data were collected from 418 apprentices in the French- and German-speaking parts of Switzerland at three measurement points: $t$, at the beginning of training; $t 2$, upon completion of training; and t3, 10 months later. Participants responded to a written questionnaire.

Findings: Ten months after completing their apprenticeships, the majority of participating young people were either employed or continuing their education. Results of the multinomial logistic and linear regressions showed a differentiated, rather than uniform, picture depending on the criteria for career success. The background factors of gender and school (9th grade) were associated with objective success after the apprenticeship ended but not
\end{abstract}

${ }^{\star}$ Corresponding author: claudia.hofmann@hfh.ch 
with subjective career success (hypothesis 1). For the variables concerning person disposition and agency (hypothesis 2), we found two plausible associations: A positive attitude towards life helped with unemployment avoidance and a highly self-rated school performance was associated with later satisfaction. As predicted in hypothesis 3 , situational factors related to the VET company and school showed a number of significant but sometimes weak associations with objective and subjective career success. Additionally, competencies and support of VET trainers related to continuance in the learned profession.

Conclusions: The career development paths of young people are influenced by various background and personality factors, as well as the training situation. VET trainers should be aware of their crucial role and understand how their interventions affect apprentices' self-perceptions and perceptions of their learned professions, which consequently influence their motivations and career aspirations. The situation at the VET school (as a learning and social place) is equally important, especially because of the aim to increase permeability for further training. Young people not in employment, education or training (NEET) are of particular concern. Even though this group is smaller in Switzerland than in most other countries, a number of problematic symptoms can be detected during apprenticeship that point to the need for the prevention of a later NEET status.

Keywords: Vocational Education and Training, VET, Special Education, Career Development, Outcomes of Education and Training, Employment

\section{Introduction}

The transition from school to work has become a political issue in Switzerland because of its lengthening and complexification (Bergman et al., 2011; Sacchi \& Meyer, 2016). In this context, transition is an even bigger challenge for young people with special educational needs, those with a migration background, and youth at risk in general (Hofmann \& Schellenberg, 2019; Bynner, 2012; Schmid, 2020). These young people may have specific problems finding suitable apprenticeships and fulfilling the relevant requirements. Furthermore, they have a higher risk of dropping out of training programmes (Hupka \& Stalder, 2011). This situation is not unique to Switzerland; it is a concern for other European countries also (Bergman et al., 2011; Fasching et al., 2017). Accordingly, there is much concern about young people who do not succeed - those who are not employed or receiving education or applicable training (NEET status; Carcillo \& Königs, 2015). Moreover, there is still insufficient information about the career development of youths with special educational needs, especially regarding factors that facilitate the transition from VET to the labour market for this group. 
Qualifications at the upper secondary level have proven to be one especially important factor for labour market opportunities (Carcillo \& Königs, 2015). In this context, "dual" systems for apprenticeship training with two learning places-the training company and the vocational school-have turned out to be particularly successful (Robson, 2010). In Switzerland, two-thirds of young people follow this pathway after completing their compulsory schooling (Stalder \& Nägele, 2011). Youths with special needs, as well as those with linguistic or behavioural difficulties, are often guided towards a two-year programme with a federal VET certificate, which is a low-threshold alternative to the three- or four-year federal VET diploma (Hofmann \& Müller, 2017; Hofmann, 2019). Apprenticeship training follows a standardised programme focused on practical activities and can be fulfilled for approximately fifty occupations. When this programme was introduced, experts in the field of special education were concerned about the increased demands. As a consequence, the association of institutions for people with handicaps, INSOS (Nationaler Branchenverband der Institutionen für Menschen mit Behinderung), introduced another two-year programme called "Practical Training" to bridge the gap to the basic federal VET programme. Both low-threshold programmes aim to improve employability and to ensure that young professionals meet the demands of the labour market in their learned professions. The results of a previous longitudinal study (Kammermann, 2010) confirmed that the chances of finding jobs in firms other than the training firms have increased; permeability for further training has also improved. Nevertheless, $12 \%$ of the young people in this study were unemployed after completing their apprenticeships-a higher figure than the average unemployment rate of $6 \%$ for those aged 15-24 years in Switzerland (BFS, 2019).

This highlights the importance of knowing more about other important influencing factors related to the transition from VET to employment. Besides social background and individual resources, support and counselling are important for promoting a smooth transition for this special group of young people, according to previous studies (Kammermann, 2010). In this paper, we refer to a socio-ecological model in which dimensions of agency, as well as social resources in the proximal settings of the social context (family, migration), are considered (Schoon \& Lyons-Amos, 2017). During the transition period, the training or work setting can also be important (Fouad \& Bynner, 2008). According to a previous study in the context of low-threshold apprenticeships, skill variety and support from the trainer play important roles in career development following the completion of training (Hofmann et al., 2014). Moreover, a general question remains regarding how to measure career success or successful school-to-work transition for disadvantaged young people. Typically, career success is differentiated by objective (e.g. status, salary) and subjective aspects (e.g. career satisfaction) (Ng et al., 2005). However, Heslin (2005) avers that the different contexts of work life should also be taken into account. For the training period, perseverance and successful completion, as well as entry into a job or further training (e.g. higher vocational education), are important 
objective indicators (Häfeli \& Schellenberg, 2009). It is also important to consider if young people are finding adequate jobs in their professions or if they have to take any job they can get. Subjective indicators are, for example, training satisfaction or later work satisfaction.

\section{Theoretical Background}

\subsection{Social Background}

First, we look at how background factors, such as socioeconomic status or parental interest, migrant status, or region, influence career success early in one's career. Research results confirm the persistent effect of socio-demographic factors that shape school and professional success and, especially, the pathway to higher academic education (Becker \& Schulze, 2013; Nägele et al., 2018). Specifically, in a comparison of different OECD countries (Organisation for Economic Co-operation and Development), NEET status is influenced by such background factors as the socioeconomic level of parents (status) and parental education (Carcillo \& Königs, 2015). In British longitudinal studies, parental education and parental interest in a child's education play significant roles in predicting different educational paths, especially NEET status (Bynner \& Parsons, 2002; Schoon \& Lyons-Amos, 2017). In the Swiss TREE panel study, socioeconomic background, migrant status, gender, and region were influential for career success (Hupka-Brunner et al., 2015; Meyer, 2018). A German study shows disadvantages of migrant youth (especially the first generation) in a comparison with non-migrant youth, even when other influencing factors, such as social origin, are taken into account (Beicht \& Walden, 2019). Finally, the influence of gender on career success has repeatedly been demonstrated. In most measures, existing studies show disadvantages for women (Meyer, 2018; Robson, 2010; Schoon \& Lyons-Amos, 2017).

Another important predictor of NEET status (more generally, later career success) is the individual's educational achievement during compulsory schooling (Bynner \& Parsons, 2002; Häfeli \& Schellenberg, 2009). Educational achievement is influenced by socioeconomic background and migrant status, but even when these factors are controlled for, early school success is linked to later career success. This holds true also for students with disabilities or special educational needs (SENs). Early tracking into special classes-compared to inclusive schooling-has negative long-term effects on VET entry or self-esteem for students with matched abilities and family backgrounds (Eckhart \& Sahli Lozano, 2014). However, in another Swiss study, apprentices from SEN backgrounds had a similar rate for labour market entry when compared with those of non-SEN backgrounds, even though they experienced a slower start (Hofmann \& Häfeli, 2015). These groups completed a two-year Federal VET certificate, which seemed to be well-suited to the needs of disadvantaged youth. 


\subsection{Individual Disposition and Agency}

The literature on career success shows the influence of a variety of personality characteristics, such as cognitive ability, personality traits, and learning motivation (Ng et al., 2005; Roberts et al., 2007).

An American study shows that disability-specifically, cognitive/learning disability, rather than physical disability-is strongly connected to disadvantaged pathways, mainly because it affects educational attainment and has effects consistently larger than several sociodemographic indicators (Erickson \& MacMillan, 2018). In Switzerland, high Programme for International Student Assessment (PISA) reading literacy scores at the end of compulsory schooling are strong predictors for enrolling in tertiary education later (Hupka-Brunner et al., 2015; Meyer, 2018). However, results from the same dataset also show that even young people with low or exceptionally low reading literacy scores can successfully complete vocational education in the Swiss context (Buchholz et al., 2012).

Noncognitive skills (i.e. personality traits, such as conscientiousness, emotional stability, and openness) are just as predictive as cognitive ability or socioeconomic background for a range of outcomes, including educational attainment, labour market performance, and health status (Ng et al., 2005; Roberts et al., 2007). These general findings from meta-analytic studies are supported in a review on NEET research (Carcillo \& Königs, 2015). In a German project, the important role of personality traits and vocational interests in securing success (satisfaction and dropout intention) in the first months of VET is demonstrated (Volodina et al., 2015). However, a Dutch study on vocational education cites no significant association between first-year dropout cases and, respectively, personality traits and cognitive skills (Eegdeman et al., 2018).

Self-efficacy and learning motivation are concepts related to certain personality traits, such as conscientiousness and emotional stability. School engagement and academic selfconcepts (as indicators of self-efficacy) are associated with distinct pathways (such as NEET), according to an English study (Schoon \& Lyons-Amos, 2017).

\subsection{Factors Related to Vocational Training and Work}

In addition to influences from social background or personality traits, situational factors related to vocational training and work can be important (Humphrey et al., 2007). These factors would be particularly relevant for the design and improvement of training. A first characteristic of the interaction between the person and work situation is the personenvironment fit (PE fit). Results in a heterogeneous sample of French employees indicate that PE fit relates positively to job satisfaction and negatively to burnout and turnover intention (Andela \& van der Doef, 2018). Among Swiss apprentices, perceived fit with the occupation 
is a good predictor of job satisfaction and the intention to complete training (Nägele \& Neuenschwander, 2015).

Various workplace characteristics (e.g. learning opportunities, autonomy, and skill variety) seem to have positive outcome effects (Humphrey et al., 2007). In a Swiss study on VET careers, learning opportunities-not socio-demographic factors-predicted engagement in higher vocational education (Nägele et al., 2018). Additionally, job resources (influence at work and opportunities for development) seem to protect against occupational turnover in the European nursing sector, whereas job demands (emotional demands and work-home-interference) are positively related to turnover (Van der Heijden et al., 2018). For Swiss apprentices with lower qualifications, skill variety relevant to the workplace and absence of stress while in vocational school contribute to staying employed after VET or continuing with further training (Hofmann \& Häfeli, 2015; Stalder, 2012).

Finally, social support in the training environment is important, especially for young people with learning or other difficulties (Hofmann et al., 2014). It has been shown to influence competency development in vocational school (Neuenschwander et al., 2007), selfesteem (Linnehan, 2003), and future career satisfaction (Ng et al., 2005). Results of a Swiss study showed that the VET teacher's support was directly and indirectly related to career aspirations at the end of an apprenticeship, whereas the VET trainer's support influenced career aspirations only indirectly (Hofmann et al., 2014).

\subsection{Hypotheses}

The meta-analysis by $\mathrm{Ng}$ et al. (2005) showed that socio-demographic factors and "human capital" (e.g. training/work-related experience) tended to influence objective career success, whereas organisational support and stable personality traits were likely to predict subjective career success. Accordingly, Schoon and Lyons-Amos (2017) argued that if the demands of the developmental transitions are not matched to the capabilities of the individual or if they amplify previous difficulties, there can be a negative effect on mental health and well-being. This argument also refers to the concept of fit and perception of fit, a central theme in works on transition and training paths (Neuenschwander \& Gerber, 2014). The fit between the requirements of training paths and the skills and interests of targeted youths is an important influencing factor on subjective and objective career success. Based on the literature cited, we assumed the following:

1. Socio-demographic factors (e.g. gender, parental education, migration status) have only a marginal influence on objective career success because earlier selection processes are more crucial. 
2. Individual disposition (e.g. effort/concentration, life attitude) influence subjective career success.

3. Training and work conditions (e.g. skill variety, fit perception) have an influence on objective and subjective career success.

Figure 1 summarises the influencing factors relevant in the context of this study.

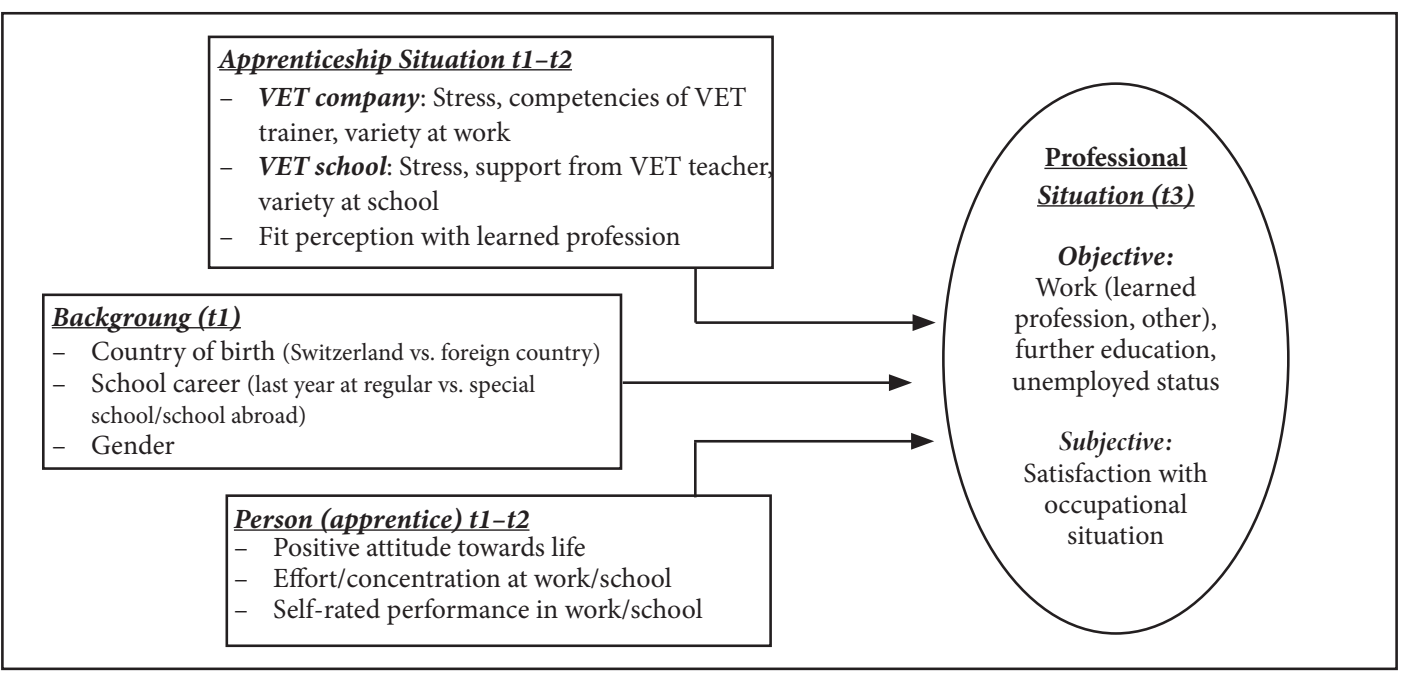

Figure 1: Relationships Between Background, Apprenticeship Situation, Persons, and Later Occupational Situation

\section{Method}

\subsection{Participants and Procedures}

Data were collected in the French- and German-speaking parts of Switzerland from four sectors of the federal VET certificate and practical training: Gastronomy, joinery, home economics, and building. These four sectors (out of approximately 50 occupations) were chosen for different reasons. They are numerically important (number of contracts) and some were already taken into account in previous studies, which allows for comparisons. The sectors vary in their content and in their gender composition. Furthermore, there is much concern about the number of early interruptions of the training in the building and gastronomy sector, which is an important question for the whole study. For our analyses, sectors were not taken into account because there were no indications of differences between sectors concerning 
the question of how different factors relate to career outcomes. There were three measurement points. The first (Tt1) took place in autumn 2016 when participants were beginning their two-year vocational training programme. T1 took place at the Vocational School with 788 participants that responded to a written questionnaire in a classroom setting (everybody present on that day, thus response rate was $100 \%$ ). They were asked about their backgrounds, career choices, and current apprenticeship situations. The researchers were present during data collection to provide assistance. T2 took place in spring 2018 at the end of the training programme (714 participants) ${ }^{1}$. The procedure was the same as that for $t 1$. Apprentices were asked about their situations at school and companies; additionally, they were asked about their future perspectives. T3 followed in summer 2019, 10 months after training ended (424 participants) ${ }^{2}$. Each participant received a letter and questionnaire. Those who did not answer were contacted by phone and asked to respond orally to the questions. Again, they were asked about their current situations.

In this study, data of persons who participated either in all three measurement points, or at $\mathrm{t} 1$ and $\mathrm{t} 3$, or at $\mathrm{t} 2$ and $\mathrm{t} 3$, were included in the analyses (a total of 418 participants). The mean age of participants at $\mathrm{t} 1$ was 18.97 years ( $\mathrm{SD}=4.33)$; 40.4\% were females. Regarding the qualification level, $81.6 \%$ were basic VET certificate learners and $18.4 \%$ were practical training learners. Sectors were represented as follows: $23.4 \%$, joinery; $19.9 \%$, building; $29.7 \%$, gastronomy; and 25.4\%, home economics. Additionally, $1.7 \%$ were from other training sectors.

\subsection{Measures}

\section{Background}

At $\mathrm{t} 1$, all participants were asked about country of birth, educational backgrounds of their parents, and school setting for each year of compulsory education (regular school, special school, or special classes).

\section{Stress at the VET Company}

Stress at the VET company was measured with a scale based on research by Semmer et al. (1999) consisting of five items (e.g. "Time-pressure at work is high", "I have to do difficult things that I have not yet learned"). Participants answered on a Likert scale ranging from $1=$ "very rarely/never" to 5 = "very often". At t1, Cronbach's a was .75; at t2, it was .76.

1 Some apprentices prematurely dropped out of the VET, others entered because they were downgraded from the VET diploma, thus the composition of the sample changed.

2 The analysis of missing data shows no significant systematic dropouts regarding gender, former school career, migration background, sectors. This is also true for the scales that we used in our analyses with one exception: Perceived fit is higher for participants compared to non-participants (only answering at $\mathrm{t} 1$ or at $\mathrm{t} 1$ and $\mathrm{t} 2$ ). 


\section{VET Trainers' Competencies}

Participants responded to four items on a scale measuring the competencies of the VET trainer, based on Neuenschwander et al. (2001) and adapted by Stalder et al. (2011). Sample items included "My VET trainer is able to explain things well" and "My VET trainer has time to answer my questions". Answers on a Likert scale ranged from $1=$ "do not agree at all" to $4=$ "fully agree". At t1, Cronbach's $\alpha$ was .82; at t2, it was .87.

\section{Skill Variety at Work}

Variety at work was measured with a scale developed by Prümper et al. (1995). The three items were as follows: "At work, I can learn a lot of new things", "My work varies", and "At work, I can use my knowledge and my skills fully". Answers on a five-point-scale ranged from $1=$ "very rarely/never" to $5=$ "very often". At t1, Cronbach's $\alpha$ was .69; at t2, it was .71.

\section{Stress at the VET School}

Stress while attending VET school was measured with a scale based on Semmer et al. (1999). It consisted of five items (e.g. "The subjects of the lessons change so fast"; "I have trouble keeping up"). Participants answered on a Likert scale ranging from $1=$ "very rarely/never" to 5 = "very often". At t1, Cronbach's $\alpha$ was .81; at t2, it was .78.

\section{Support From the VET Teacher}

Support from the VET teacher was measured with one item based on a scale developed by Frese (1999) and adapted by Stalder et al. (2011). The introductory question was "How interested are the following persons in your training situation?", followed by a list of supportive persons, including the teacher. Answers on the Likert scale ranged from 1 = "not at all" to 4 = "very".

\section{Skill Variety at School}

Variety at school was measured with a scale developed by Prümper et al. (1995). The two items were as follows: "I can learn a lot in class" and "The lessons are varied". The answer format was a scale ranging from $1=$ "very rarely/never" to $5=$ "very often". Cronbach's $\alpha$ was .58 at $\mathrm{t} 1(\mathrm{r}=.42)$ and $.58(\mathrm{r}=.41)$ at $\mathrm{t} 2$.

\section{Perceived fit}

The person-occupation fit was measured with five items from Neuenschwander et al. (2013) describing how well an occupation fits in terms of an individual's personality and abilities (e.g. "My apprenticeship training fits my personality"). The scale for responses ranged from $1=$ "do not agree at all" to $4=$ "fully agree". At t1, Cronbach's a'was .82; at t2, it was .84.

\section{Effort/Commitment at Work}

Effort and commitment at the company were measured with two items: "Good performance at the VET company is important to me" and "I show great effort at the VET company" (scale 
adapted by Moser, 1997). The answer format was a scale from $1=$ "do not agree at all" to $4=$ "fully agree". Cronbach's $\alpha$ was .55 at $\mathrm{t} 1(\mathrm{r}=.39)$ and $.59(\mathrm{r}=.42)$ at $\mathrm{t} 2$.

\section{Self-Rated Performance at Work}

Self-rated performance at the VET company was evaluated with one item (i.e. "How do you assess your own performance at work?"); participants answered on a Likert scale ranging from 1 = "very bad" to 6 = "very good".

\section{Effort/Concentration at School}

Effort and concentration at school were measured with four items based on an adapted scale by Moser (1997). Sample items include "I show great effort at school" and "I concentrate fully at school". The answer format was a scale from $1=$ "do not agree at all" to $4=$ "fully agree". At t1, Cronbach's a was.76; at $\mathrm{t} 2$, it was .80 .

\section{Self-Rated Performance in School}

To measure self-rated performance in VET school, we developed a two-item scale with the following: "How do you assess your own performance in occupation-specific knowledge classes?" and "How do you assess your own performance in general subject classes?". Answers on the Likert scale ranged from $1=$ "very bad" to $6=$ "very good.". Cronbach's $\alpha$ was .71 at t $1(\mathrm{r}$ $=.55)$ and $.66(\mathrm{r}=.49)$ at $\mathrm{t} 2$.

\section{Positive Attitude Towards Life}

A positive attitude towards life was measured with four items based on a scale from Grob et al. (1991). Sample items include "Whatever happens, I can see the good side of it" and "I like to live". The Likert scale ranged from $1=$ "totally wrong" to $5=$ "totally true". At t1, Cronbach's a was .72; at t2, it was .77.

\section{Objective Situation at $t 3$}

The former apprentices described their actual occupational situations by selecting one of several options (e.g. working in their learned profession ${ }^{3}$, undertaking further education in the learned profession or another educational field, unemployed, etc.).

\section{Satisfaction With the Situation at 13}

Satisfaction with one's situation was measured with an adapted item based on Kammermann et al. (2009). The introductory question was different depending on the situation. For participants in work situations, it was "How satisfied are you with your situation at work?"; for participants pursuing further education, it was "How satisfied are you with your training situation?". For all others (NEET), it was "How satisfied are you with your situation?". Answers ranged from 1 = "extraordinarily unsatisfied" to 7 = "extraordinarily satisfied".

3 Learned profession means that the former apprentices work in the same field where their training took place. 
For our analyses, we computed the means of the two scales ( $\mathrm{t} 1$ and $\mathrm{t} 2$ ) and entered these new variables as independent variables. Means, standard deviations, and bivariate correlations between all included independent variables are presented in Table 1. Correlations between the variables were weak to moderate.

Table 1: Descriptions of and Correlations Between Independent Variables

\begin{tabular}{|c|c|c|c|c|c|c|c|c|c|c|c|c|c|c|c|}
\hline & & $\mathrm{N}$ & M & SD & 1 & 2 & 3 & 4 & 5 & 6 & 7 & 8 & 9 & 10 & 11 \\
\hline 1 & Stress at work & 417 & 2.66 & .67 & - & & & & & & & & & & \\
\hline 2 & $\begin{array}{l}\text { Competencies of } \\
\text { VET trainer }\end{array}$ & 409 & 3.34 & .57 & $-.12^{*}$ & - & & & & & & & & & \\
\hline 3 & Variety at work & 417 & 3.92 & .63 & .02 & $.52^{* *}$ & - & & & & & & & & \\
\hline 4 & Stress at school & 414 & 2.28 & .74 & $.42^{\star *}$ & .04 & -.01 & - & & & & & & & \\
\hline 5 & $\begin{array}{l}\text { Support from } \\
\text { VET teacher }\end{array}$ & 414 & 3.33 & .71 & .07 & $.11^{*}$ & $.18^{* *}$ & $.10^{*}$ & - & & & & & & \\
\hline 6 & Variety at school & 417 & 3.94 & .65 & .00 & .08 & $.29^{* *}$ & .01 & $.29^{* *}$ & - & & & & & \\
\hline 7 & $\begin{array}{l}\text { Perceived fit w/ } \\
\text { learned profession }\end{array}$ & 416 & 3.20 & .51 & -.01 & $.35^{* *}$ & $.44^{* *}$ & .06 & $.23^{* *}$ & $.25^{* *}$ & - & & & & \\
\hline 8 & $\begin{array}{l}\text { Effort/commit- } \\
\text { ment at work }\end{array}$ & 418 & 3.44 & .48 & -.02 & $.33^{* *}$ & $.44^{\star *}$ & $-.13^{* *}$ & $.15^{\star *}$ & $.19^{* *}$ & $.33^{* *}$ & - & & & \\
\hline 9 & $\begin{array}{l}\text { Performance at } \\
\text { work (self-rated) }\end{array}$ & 418 & 4.86 & .64 & -.05 & $.30^{* *}$ & $.32^{* *}$ & .04 & $.15^{* *}$ & $.13^{* *}$ & $.36^{* *}$ & $.21^{* *}$ & - & & \\
\hline 10 & $\begin{array}{l}\text { Effort/concen- } \\
\text { tration at school }\end{array}$ & 407 & 3.18 & .48 & $.11^{*}$ & $.17^{* *}$ & $.29^{* *}$ & .01 & $.25^{\star *}$ & $.45^{\star *}$ & $.35^{\star *}$ & $.37^{* *}$ & $.19^{* *}$ & - & \\
\hline 11 & $\begin{array}{l}\text { Performance in } \\
\text { school (self-rated) }\end{array}$ & 418 & 4.70 & .66 & .06 & $.13^{*}$ & $.22^{\star *}$ & $-.16^{* *}$ & $.17^{\star *}$ & $.27^{* *}$ & $.30^{* *}$ & $.17^{* *}$ & $.31^{* *}$ & $.41^{* *}$ & - \\
\hline 12 & $\begin{array}{l}\text { Positive attitude } \\
\text { towards life }\end{array}$ & 415 & 3.98 & .64 & .02 & $.21^{* *}$ & $.31^{* *}$ & .02 & $.16^{* *}$ & $.21^{* *}$ & $.32^{\star *}$ & $.21^{* *}$ & $.30^{* *}$ & $.31^{* *}$ & $.31^{* *}$ \\
\hline
\end{tabular}

Note. ${ }^{*} \mathrm{p}<.05 .{ }^{* *} \mathrm{p}<.01 ; \mathrm{M}=$ mean; $\mathrm{SD}=$ standard deviation; $\mathrm{VET}=$ vocational education and training.

\section{$4 \quad$ Results}

\subsection{Occupational Situation After Apprenticeship}

Ten months after their apprenticeships ended, around $80 \%$ of the former basic VET certificate learners and practical learners stated that they were either employed or continuing their education. Table 2 shows the situation of both groups in more detail. 
Table 2: Occupational Situation at t3 (10 Months After Completion of Apprenticeship)

\begin{tabular}{|c|c|c|c|c|c|c|}
\hline & \multicolumn{2}{|c|}{$\begin{array}{c}\text { Basic VET } \\
\text { certificate learners }\end{array}$} & \multicolumn{2}{|c|}{$\begin{array}{l}\text { Practical } \\
\text { training learners }\end{array}$} & \multicolumn{2}{|c|}{ Total } \\
\hline & $\mathrm{N}$ & $\%$ & $\mathrm{~N}$ & $\%$ & $\mathrm{~N}$ & $\%$ \\
\hline Employed in learned profession & 123 & 36.6 & 38 & 49.4 & 161 & 39.0 \\
\hline Other employment & 33 & 9.8 & 21 & 27.2 & 54 & 13.1 \\
\hline $\begin{array}{l}\text { Further training in learned } \\
\text { profession }\end{array}$ & 89 & 26.5 & 6 & 7.8 & 95 & 23.0 \\
\hline Other further education & 13 & 3.9 & 1 & 1.3 & 14 & 3.4 \\
\hline Unemployed & 44 & 13.1 & 7 & 9.1 & 51 & 12.3 \\
\hline Other situation* ${ }^{*}$ & 34 & 10.1 & 4 & 5.2 & 38 & 9.2 \\
\hline Total & 336 & 100.0 & 77 & 100.0 & 413 & 100.0 \\
\hline
\end{tabular}

Note. ${ }^{*}$ e.g. military services, parenthood, illness; VET = vocational education and training.

When questioned, $39 \%$ of the former learners (both groups) were employed in their learned professions, approximately $26 \%$ were pursuing further education, and $12 \%$ were unemployed. The situations for former basic VET certificate learners and practical training learners differed significantly $(\chi 2(5)=30.41, \mathrm{p}<.001)$. Former basic VET certificate learners were more often receiving further training (mostly in their learned professions) compared to former practical learners. Former practical learners were more often employed in their learned or other occupations. Additional analyses showed that $86.3 \%$ of the former VET certificate learners were working in the first labour market compared to only $49.1 \%$ of the former practical learners. The "unemployed" rate did not differ significantly (13\% vs. $9 \%)$. In both groups, the number of people not in an occupational situation but also not unemployed ("other situation", such as parenthood or military service) was relatively high at $9 \%$.

\subsection{Influencing Factors on Later Occupational Situation (Objective Career Success)}

To assess the association between background and apprenticeship situation and later occupational situation, the latter was used as the dependent variable in a multinomial logistic regression; the group with former learners working in their learned professions was the reference group (largest group; $\mathrm{N}=132$ ). For these analyses, we added VET certificate and practical learners, but only four groups were considered-employment in learned profession, other employment, further education in learned profession, and unemployed status-because the two other groups (other further education and other situation) were rather small and heterogenous. 
Table 3 presents the comparison between the reference group and the remaining three other groups for the influence of background variables, apprenticeship situation, and individual disposition/agency.

Table 3: Predicting Occupational Situation After Apprenticeship (Multinomial Logistic Regression Analysis; Reference Group: Employed in Learned Profession, $N=132)^{4}$

\begin{tabular}{|c|c|c|c|c|c|c|}
\hline & \multicolumn{2}{|c|}{$\begin{array}{l}\text { Other employment } \\
(\mathrm{N}=46)\end{array}$} & \multirow{2}{*}{$\begin{array}{l}\begin{array}{l}\text { Unemployed } \\
\text { (NEET) }\end{array} \\
(\mathrm{N}=45) \\
\text { B }\end{array}$} & & \multicolumn{2}{|c|}{$\begin{array}{l}\text { Further training in } \\
\text { learned profession } \\
(\mathrm{N}=80)\end{array}$} \\
\hline & $\mathrm{B}$ & $\operatorname{Exp}(B)$ & & $\operatorname{Exp}(B)$ & B & $\operatorname{Exp}(B)$ \\
\hline \multicolumn{7}{|l|}{ Background } \\
\hline Gender $(1=$ female, $2=$ male $)$ & $.76^{*}$ & 2.14 & .36 & 1.44 & $.66^{*}$ & 1.94 \\
\hline Country of birth ( $1=$ Swiss origin, $2=$ broad $)$ & $.16 \mathrm{x}$ & 1.18 & -.09 & .92 & .21 & 1.24 \\
\hline School at $9^{\text {th }}$ grade $(1=$ regular, $2=$ special $)$ & $1.04^{*}$ & 2.82 & .05 & 1.05 & -.29 & .75 \\
\hline \multicolumn{7}{|l|}{ Situation at the VET company } \\
\hline Stress at work & -.17 & .85 & -.29 & .75 & -.39 & .68 \\
\hline Competencies of VET trainer & $-1.12^{* *}$ & .33 & -.27 & .76 & -.38 & .69 \\
\hline Variety at work & .46 & 1.58 & .26 & 1.30 & .39 & 1.47 \\
\hline \multicolumn{7}{|l|}{ Situation at the VET school } \\
\hline Stress at school & -.14 & .87 & $.50^{\mathrm{t}}$ & 1.65 & $-.47^{\mathrm{t}}$ & .62 \\
\hline Support from VET teacher & .43 & 1.53 & .05 & 1.05 & -.04 & .96 \\
\hline Variety at school & -.49 & .61 & .10 & 1.10 & -.08 & .92 \\
\hline Perceived fit with learned profession & .23 & 1.26 & $-.75^{\mathrm{t}}$ & .47 & .23 & 1.26 \\
\hline \multicolumn{7}{|l|}{ Person } \\
\hline Effort/commitment at work & -.32 & .83 & .13 & 1.13 & .37 & 1.40 \\
\hline Performance at work (self-rated) & .26 & 1.30 & -.17 & .84 & -.28 & .76 \\
\hline Effort/concentration at school & -.11 & .90 & -.03 & .97 & .24 & 1.27 \\
\hline Performance in school (self-rated) & -.25 & .78 & .25 & 1.29 & .30 & 1.35 \\
\hline Positive attitude towards life & -.01 & .99 & $-.61^{*}$ & .54 & -.22 & .80 \\
\hline
\end{tabular}

Note. ${ }^{\mathrm{t}} \mathrm{p}<.10,{ }^{*} \mathrm{p}<.05,{ }^{*} \mathrm{p}<.01 ;$ Pseudo $-\mathrm{R}^{2}(\mathrm{Cox} \&$ Snell $)=.20 ; \mathrm{B}=$ regression coefficient; Exp $(\mathrm{B})=$ odds ratio ${ }^{5}$; $\mathrm{VET}=$ vocational education and training; NEET $=$ not employed or in education.

First, we compared former learners who were working in their learned professions (reference group $=0$ ) with former learners working in another occupation $(=1)$. Regarding the back-

4 Parental education was included as an independent variable in our first analyses, but it reduced $\mathrm{N}$ substantially because of missing values. Moreover, it was not a significant predictor in the analyses.

$5 \operatorname{Exp}$ (B) can be interpreted in terms of the change of odds: If the value is greater than 1 then it indicates that as the predictor increases, the odds of the outcomes increase (conversely decrease when it is less than one, see also Cohen et al., 2003). E.g. males probability of further training is nearly twice as high compared to women. 
ground variables, we found two significant associations: Being male as well as finishing the $9^{\text {th }}$ grade in a special school increased the likelihood of working in an occupation other than the learned one. Regarding the apprenticeship situation, there was only one significant effect: Those who rated the competencies of the VET trainer more positively were less likely to work in another occupation. All other variables of the situation at the VET company and VET school had no significant influence. Moreover, there was no significant effect of person variables.

The second comparison concerned former learners who were working in their learned professions (reference group $=0$ ) and former learners who were unemployed $(=1)$. None of the background variables had a significant influence here. Situation at the VET company was not relevant either. However, there was one nearly significant effect of the situation at the VET school: Learners who experienced more stress while attending VET school were more likely to be unemployed 10 months after their apprenticeships ended $(\mathrm{p}<.10)$. Additionally, the perceived fit with the learned profession (rated at $\mathrm{t} 1 / \mathrm{t} 2$ ) decreased the likelihood of being unemployed later $(\mathrm{p}<.10)$. One significant effect was found with the person variable: Those with more positive attitudes towards life were less likely to be unemployed 10 months after completing their apprenticeships.

Finally, we compared former learners who were working in their learned professions (reference group $=0$ ) with former learners who were undertaking further education in their learned professions $(=1)$. Concerning the background variables, we found that being male increased the likelihood of such an undertaking. Apprenticeship situation had one nearly significant influence $(\mathrm{p}=.06)$ : Learners who experienced less stress at VET school were more likely to undertake further education in their learned professions. None of the person variables reached statistical significance.

\subsection{Influencing Factors for Later Satisfaction With the Situation (Subjective Career Success)}

To assess the association between the training situation and future subjective career success, we chose the same independent variables as in the previous analyses and conducted analyses with the same sample. Model 1 includes the background variables, apprenticeship situation, and person variables. For Model 2, we added a dichotomous variable for the occupational situation 10 months after the apprenticeship ended (see Table 2, employed/further education groups [1-3] vs. unemployed/NEET [group 5]). Table 4 presents the results of the two linear regressions. 
Table 4: Predicting Satisfaction With Situation 10 Months After Completion of Apprenticeship (Linear Regression, $N=300$ )

\begin{tabular}{|c|c|c|c|c|}
\hline & \multicolumn{2}{|c|}{ Model 1} & \multicolumn{2}{|c|}{ Model 2} \\
\hline & B & SE & B & SE \\
\hline \multicolumn{5}{|l|}{ Background } \\
\hline Gender $(1=$ female, 2 = male $)$ & -.16 & .17 & -.01 & .14 \\
\hline Country of birth ( $1=$ Swiss origin, $2=$ abroad $)$ & .03 & .19 & .01 & .16 \\
\hline School at 9th grade $(1=$ regular, $2=$ special $)$ & -.02 & .18 & -.02 & .15 \\
\hline \multicolumn{5}{|l|}{ Situation at VET company } \\
\hline Stress at work & -.08 & .14 & $-.10^{\mathrm{t}}$ & .12 \\
\hline Competencies of VET trainer & -.06 & .18 & -.05 & .15 \\
\hline Variety at work & $.22^{* *}$ & .18 & $.23^{* * *}$ & .15 \\
\hline \multicolumn{5}{|l|}{ Situation at VET school } \\
\hline Stress at school & -.02 & .13 & .06 & .11 \\
\hline Support from VET teacher & .04 & .13 & .04 & .10 \\
\hline Variety at school & $-.12^{\mathrm{t}}$ & .15 & $-.10^{\mathrm{t}}$ & .13 \\
\hline Perceived fit with learned profession & $.12^{\mathrm{t}}$ & .20 & .04 & .17 \\
\hline \multicolumn{5}{|l|}{ Person } \\
\hline Effort/commitment at work & .06 & .21 & .06 & .18 \\
\hline Performance at work (self-rated) & .03 & .15 & .02 & .13 \\
\hline Effort/concentration at school & -.01 & .23 & -.01 & .19 \\
\hline Performance in school (self-rated) & .10 & .16 & $.13^{*}$ & .13 \\
\hline Positive attitude towards life & .08 & .14 & .01 & .12 \\
\hline $\begin{array}{l}\text { Situation at } t 3 \\
(0=\text { unemployed/NEET, } 1=\text { employed/further } \\
\text { education })\end{array}$ & & & $.53^{* * *}$ & .20 \\
\hline
\end{tabular}

The independent variables in Model 1 significantly explained satisfaction with the situation 10 months after the end of the apprenticeship $(F(15)=3.02, p<.001)$, but the overall explained variance was small (i.e. $\mathrm{R}^{2}=.14 ; \mathrm{R}^{2}{ }_{\text {cor }}=.09$ ). According to our analyses, skill variety at work seemed to be the most influential factor. apprentices rating variety at work at $\mathrm{t} 1$ and $\mathrm{t} 2$ more positively were also more satisfied with their situations at $\mathrm{t} 3(B=.22, \mathrm{p}<.01)$. Variety at school had an opposite effect $(\beta=-.12, \mathrm{p}<.10)$ : Apprentices who rated variety at VET school more positively were less likely to be satisfied with their situations at $t 3$. Perceived fit with the learned profession also had a weak effect in the expected direction: Apprentices perceiving a better fit at $\mathrm{t} 1$ and $\mathrm{t} 2$ were more satisfied with their situations at $\mathrm{t} 3(\beta=.12, \mathrm{p}<.10)$.

Adding the situation at $\mathrm{t} 3$ as an independent variable to explain satisfaction at $\mathrm{t} 3$ led to a much better fit of the model $(\mathrm{F}(16)=11.68, \mathrm{p}<.001): \mathrm{R}^{2}$ is $.36\left(\mathrm{R}^{2}\right.$ cor $\left.=.40\right)$. The situation at $\mathrm{t} 3$ 
had the strongest effect: Young workers or students pursuing further education were far more satisfied with their situations than persons of NEET status $(B=.53, \mathrm{p}<.001)$. Even when controlling for this variable, variety of work at the VET company was still important: Those who perceived more variety at work during the apprenticeship were more satisfied with their situations later $(\beta=.23, \mathrm{p}<.001)$. In addition, stress at the VET company during apprenticeship had a weak, negative effect on later satisfaction with the situation in Model $2(\beta=-.10, p$ $<.10)$. Furthermore, the weak, negative effect of variety at VET school persisted in this model $(ß=-.10, p<.10)$. Finally, we found that performance at VET school significantly influenced later satisfaction with one's situation $(\beta=.13, \mathrm{p}<.05)$.

\section{Discussion and Conclusions}

\subsection{Discussion}

Looking at the careers of young people in low-threshold VET programmes in Switzerland, we found that 10 months after completing their apprenticeships, the majority (80\%) were either employed or pursuing further education. Already, the heterogeneity of occupational pathways was evident, though these young people were in the early period of work life. In our study, we took a broad perspective regarding possible influences on the pathways, which included indicators of objective and subjective career success. We not only looked at social background, personal disposition, and agency, but we also included the training situation, thus expanding the socio-ecological model of human agency (Schoon \& Lyons-Amos, 2017). While trying to become independent from their families, young people aged 16-20 might be especially receptive to workplace influences as well as those at the VET schools.

Results of the multinomial logistic and linear regressions showed a differentiated picture, rather than a uniform one, depending on the criteria for career success. For example, background factors of gender and school ( $9^{\text {th }}$ grade) were associated with one's objective status after completion of the apprenticeship but not with subjective career success (hypothesis 1). As in other studies, young men, even at this early stage, demonstrated greater career success than women by continuing their education at the next level (Hupka-Brunner et al., 2015; Schoon \& Lyons-Amos, 2017). The basis for this finding is probably related to the sectors in which males were working, where further education is generally expected and valued by the labour market. Their higher rates of occupational changes could be interpreted as the search for better prospects regarding pay (Müller \& Schweri, 2009) or a temporary solution until the beginning of military service.

The influence of school background persisted even after completion of a standardised training programme. People from special classes and schools were less often pursuing further 
education and more often employed in occupations other than their learned ones. These results confirm those of other studies: Early tracking and separation often continues after compulsory education (Eckhart \& Sahli Lozano, 2014). Young people with SENs are often guided towards the secondary labour market, and apprenticeships take place in specialised institutions; these situations influence future career success (Hofmann \& Schaub, 2014).

For the variables concerning person disposition and agency (hypothesis 2), we found only two plausible associations. A positive attitude towards life helps one avoid unemployment (or more generally, NEET) and a high self-rated school performance is associated with future satisfaction, which partly confirms the results of Schoon \& Lyons-Amos (2017) and Volodina et al. (2015). However, "agency" seems to be less important for the group of learners with SENs than for other groups, probably because of a selection bias. Schoon and Lyons-Amos (2017) found that people with higher aspirations were less likely to be in NEET status but also less likely to be in VET or employed. Moreover, apprentices in low-threshold training situations were usually more dependent on their social networks; generally, other external factors (e.g. unemployment rate) could have played an important role at the time of entry to the labour market (Müller \& Schweri, 2009).

As expected (hypothesis 3 ), situational factors related to the VET company and school showed a number of significant but sometimes weak associations with objective and subjective career success. So, competencies and support of the VET trainer were related to staying in the learned profession. The VET trainer probably acts as a role model and motivates this choice after apprenticeship. Surprisingly, the VET trainer's influence did not work for undertaking further education in our study, which contradicts findings of other studies (Hofmann et al., 2014; Nägele et al. 2018) but can be explained by the high correlation with other independent variables (e.g. skill variety) that mediate these associations. However, one of two predictors of further education was stress experienced at VET school, which seems to undermine the intention to continue one's education. In view of the higher intellectual demands to obtain a VET diploma, this is comprehensible. The other (even stronger) predictor is perceived fit with the learned profession, which is confirmed by other studies (Andela \& van der Doef, 2018; Nägele \& Neuenschwander, 2015). Another important factor-not for objective but for subjective career success-is skill variety at the VET company (Humphrey et al., 2007). Apprentices who rated skill variety highly were more likely to be satisfied with their later situations. Stalder (2012) also found that skill variety at the VET company was related to satisfaction and successful transition to the labour market, but skill variety at VET school did not have that effect. We found the same surprising result; apprentices who rated variety at VET school positively were less satisfied with their later work situations. It is likely that those who enjoyed being intellectually challenged missed this learning place, whereas more practically skilled young people did not. 


\subsection{Limitations and Further Research}

Our findings should be interpreted in light of certain limitations. First, although we conducted our research with a special sample that was representative of young people with learning difficulties in four major fields of vocational training, this sample was not representative of young people in transition, nor did it represent young people with handicaps, learning disabilities, and other difficulties in general. Second, we were faced with the problem of missing responses at $\mathrm{t} 3$ (the labour market situation), which reduced our sample sizes, particularly for different groups needed for our comparisons. Under these circumstances, even large effect sizes might not reach statistical significance. Furthermore, there may be an effect on our results even though we analysed missing data and did not find indications of systematic drop-out. Third, we relied on self-reported data; some measures were based on single items (i.e. less stable than multi-item scales); a few scales showed only modest reliability. Finally, we observed only a short period for the transition to employment (i.e. the first 10 months). Though this is a crucial period, further research should follow the changes in transitions at later time points because former studies illustrated that the first years after training are not very stable (Hofmann \& Häfeli, 2015).

\subsection{Practical Implications}

Though the results of many studies point to various background and personality factors as related to the career development of young people, our results indicate that the situations at the VET company and VET school might compensate for some young people, especially those with disadvantages or handicaps. First, VET trainers should be aware of their crucial role and how their interventions affect apprentices' self-perceptions and perceptions of their learned professions, which consequently influence motivation and career aspirations. It is important to be aware of apprentices with special needs in VET but it is also crucial not to underestimate these young people because opportunities at the VET company (e.g. skill variety) prepare them for future work situations and facilitate their transition.

The situation at the VET school (as a learning and social place) is equally important, especially for increasing permeability towards further training. Because stress at VET school seems to be a predicting factor, it is important to be aware of the aspirations and doubts of apprentices. Furthermore, stress at VET school is also related to a later NEET status, which points to the role of VET teachers in identifying young people at risk. Young people classified as NEET are of special concern. Even though this group is smaller (12\%) in Switzerland than in most OECD countries (Carcillo \& Königs, 2015), they show a number of problematic symptoms during their apprenticeships (e.g. lower perceived fit with learned professions, less positive attitude towards life) and are less satisfied with their situations after completing VET. Programmes with a daily structure and training opportunities are important for pre- 
paring unemployed young people to enter the labour market. Assisting low-achieving youth in this effort remains challenging; the training company and VET school must support these vulnerable groups in their career development.

\section{Acknowledgement}

This contribution is based on a longitudinal study conducted by the University of Applied Sciences in Special Needs Education ( $\mathrm{HfH}$ ) and the Swiss Federal Institution for Vocational Education and Training (SFIVET), which was financed by the State Secretariat for Education (SERI).

\section{References}

Andela, M., \& van der Doef, M. (2018). A comprehensive assessment of the person - Environment fit dimensions and their relationships with work-related outcomes. Journal of Career Development, 46(5), 567-582. https://doi.org/10.1177/0894845318789512

Becker, R., \& Schulze, A. (2013). Bildungskontexte: Strukturelle Voraussetzungen und Ursachen ungleicher Bildungschancen [Contexts of education: Structural conditions and causes of unequal educational opportunities]. Springer Verlag.

Beicht, U., \& Walden, G. (2019). Transition to company-based vocational training in Germany by young people from a migrant background - The influence of region of origin and generation status. International Journal for Research in Vocational Education and Training, 6(1), 20-45. https:// doi.org/10.13152/IJRVET.6.1.2

Bergman, M. M., Hupka-Brunner, S., Keller, A., Meyer, T., \& Stalder, B. E. (Eds.) (2011). Youth transition in Switzerland. Results from the TREE panel study. Seismo.

Bundesamt für Statistik. (2019). Schweizerische Arbeitskräfteerhebung im 2. Quartal 2019: Arbeitsangebot [Swiss labour force survey in the second quarter of 2019: Supply of labour] [Press release].

Buchholz, S., Imdorf, C., Hupka-Brunner, S., \& Blossfeld, H.-P. (2012). Sind leistungsschwache Jugendliche tatsächlich nicht ausbildungsfähig? Eine Längsschnittanalyse zur beruflichen Qualifizierung von Jugendlichen mit geringen kognitiven Kompetenzen im Nachbarland Schweiz [Are academically weak youths really not ready for vocational training? A longitudinal analysis of vocational training trajectories of youths with low cognitive competencies in Switzerland]. Kölner Zeitschrift für Soziologie und Sozialpsychologie, 64(4), 701-727. https://doi.org/10.1007/s11577-012-0186-1

Bynner, J. (2012). Policy reflections guided by longitudinal study, youth training, social exclusion, and more recently NEET. British Journal of Educational Studies, 60(1), 39-52. https://doi.org/10.1080/ 00071005.2011 .650943

Bynner, J., \& Parsons, S. (2002). Social exclusion and the transition from school to work: The case of young people not in education, employment, or training (NEET). Journal of Vocational Behavior, 60(2), 289-309. https://doi.org/10.1006/jvbe.2001.1868 
Carcillo, S., \& Königs, S. (2015). NEET youth in the aftermath of the crisis: Challenges and policies. OECD Social, Employment and Migration Working Papers, 164. https://doi.org/10.2139/ ssrn. 2573655

Cohen, J., Cohen, P., West, S. G., \& Aiken, L. S. (2003). Applied multiple regression/correlation analysis for the behavioral sciences. Routledge Taylor \& Francis Group.

Eckhart, M., \& Sahli Lozano, C. (2014). Der lange Schatten der schulischen Separation: Ergebnisse einer Längsschnittuntersuchung [The long shadow of school separation: Results of a longitudinal study]. In M. P. Neuenschwander (Ed.), Selektion in Schule und Arbeitsmarkt [Selection in school and in the labour market] (pp. 113-131). Rüegger.

Eegdeman, I., Meeter, M., \& Van Klaveren, C. (2018). Cognitive skills, personality traits and dropout in Dutch vocational education. Empirical Research in Vocational Education and Training, 10(1). https://doi.org/10.1186/s40461-018-0072-9

Erickson, G., \& MacMillan, R. (2018). Disability and the transition to adulthood: A life course contingency perspective. Longitudinal and Life Course Studies, 9(2), 188-211. https://doi.org/10.14301/ llcs.v9i2.335

Fasching, H., Geppert, C., \& Makarova, E. (2017). Inklusive Übergänge. (Inter)nationale Perspektiven auf Inklusion im Übergang von der Schule in weitere Bildung, Ausbildung oder Beschäftigung [Inclusive transitions. (Inter-)national perspectives on inclusion in the transition from school to further education, training, or employment]. Verlag Julius Klinkhardt.

Fouad, N. A., \& Bynner, J. (2008). Work transitions. American Psychologist, 63(4), 241-251. https://doi. org/10.1037/0003-066x.63.4.241

Frese, M. (1999). Social support as a moderator of the relationship between work stressors and psychological dysfuncioning: A longitudinal study with objective measures. Journal of Occupational Health Psychology, 4(3), 179-192. https://doi.org/10.1037/1076-8998.4.3.179

Grob, A., Lüthi, R., Kaiser, F., Flammer, A., Mackinnon, A., \& Wearing, A. J. (1991). Berner Fragebogen zum Wohlbefinden Jugendlicher (BFW) [Bernese questionnaire of well-being of youth]. Diagnostica, 37(1), 66-75. https://www.researchgate.net/profile/August-Flammer/publication/232538901_Berner_Fragebogen_zum_Wohlbefinden_Jugendlicher_BFW_The_Bern_Subjective_Well-Being_Questionnaire_for_Adolescents_BFW/links/542427a40cf26120b7a71fb9/ Berner-Fragebogen-zum-Wohlbefinden-Jugendlicher-BFW-The-Bern-Subjective-Well-BeingQuestionnaire-for-Adolescents-BFW.pdf

Häfeli, K., \& Schellenberg, C. (2009). Erfolgsfaktoren in der Berufsausbildung bei gefährdeten Jugendlichen. Schweizerische Konferenz der kantonalen Erziehungsdirektoren.

Heslin, P. A. (2005). Conceptualizing and evaluating career success. Journal of Organizational Behavior, 26, 113-136. https://doi.org/10.1002/job.270

Hofmann, C. (2019). Lernende in Übergangssituationen im niederschwelligen Ausbildungsbereich: Einschätzungen zur Berufswahl und ersten Erfahrungen im Lehrbetrieb und in der Schule. Sonderpädagogische Förderung heute. In C. Lindmeier, H. Fasching, B. Lindmeier \& D. Sponholz (Eds.), Inklusive Berufsorientierung und berufliche Bildung - Aktuelle Entwicklungen im deutschsprachigen Raum (pp. 358-368). Beltz Juventa.

Hofmann, C., \& Häfeli, K. (2015). Übergang in den Arbeitsmarkt nach einer Attestausbildung. In K. Häfeli, M. P. Neuenschwander \& S. Schumann (Eds.), Berufliche Passagen im Lebenslauf (pp. 189-218). VS Verlag für Sozialwissenschaften. 
Hofmann, C., \& Müller, X. (2017). Verzögerter Einstieg, aber Zufriedenheit mit zweijähriger Ausbildung. Befragung von Lernenden bei Ausbildungsbeginn zum Übergang in die Ausbildung und zu ersten Erfahrungen in Schule und Lehrbetrieb. Schweizerische Zeitschrift für Heilpädagogik, 23(10), 40-47.

Hofmann, C., \& Schaub, S. (2014). "Supported Education" im ersten Arbeitsmarkt: Ausbildungssituation und berufliche Perspektiven. Schweizerische Zeitschrift für Heilpädagogik, 20(10), 25-32. https://www.hfh.ch/sites/default/files/old/documents/Dokumente_FE/B.23_Hofmann_2014_Supported_SZH.pdf

Hofmann, C., \& Schellenberg, C. (2019). Der Übergang Schule - (Aus-)Bildung - Beschäftigung in der Schweiz. Ein Überblick mit Fokus auf die berufliche Ausbildung. In C. Lindmeier, H. Fasching, B. Lindmeier \& D. Sponholz (Eds.), Inklusive Berufsorientierung und berufliche Bildung - Aktuelle Entwicklungen im deutschsprachigen Raum (1st ed., pp. 194-219). 2. Beiheft Sonderpädagogische Förderung heute. Beltz.

Hofmann, C., Stalder, B. E., Tschan, F., \& Häfeli, K. (2014). Support from teachers and trainers in vocational education and training: The pathways to career aspirations and further career development. International Journal for Research in Vocational Education and Training, 1(1), 1-20. https://doi. org/10.13152/IJRVET.1.1.5

Humphrey, S. E., Nahrgang, J. D., \& Morgeson, F. P. (2007). Integrating motivational, social, and contextual work design features: A meta-analytic summary and theoretical extension of the work design literature. Journal of Applied Psychology, 92(5), 1332-1356. https://doi.org/10.1037/00219010.92.5.1332

Hupka-Brunner, S., Scharenberg, K., Meyer, T., \& Müller, B. (2015). Leistung oder soziale Herkunft [Performance or social origin]? In K. Häfeli, M. P. Neuenschwander \& S. Schumann (Eds.), Berufliche Passagen im Lebenslauf [Occupational transitions in the life course] (pp. 243-276). VS Verlag für Sozialwissenschaften.

Hupka, S., \& Stalder, B. E. (2011). Jeunes migrantes et migrants à la charnière du secondaire I et du secondaire II [The situation of young migrants making the transition from lower to upper secondary education]. In M. M. Bergman, S. Hupka-Brunner, K. A. T. Meyer \& B. E. Stalder (Eds.), Transitions juvéniles en Suisse. Résultats de l'étude longitudinale TREE [Youth transitions in Switzerland: Results from the TREE panel study] (pp. 183-200). Seismo.

Kammermann, M. (2010). Job or further training? Impact of the Swiss basic federal vocational education and training (VET) certificate on the careers of low achieving young people. Education + Training, 52(5), 391-403. https://doi.org/10.1108/00400911011058334

Kammermann, M., Hofmann, C., \& Hättich, A. (2009). Forschungsprojekt Arbeitsmarktfähigkeit und zweijährige berufliche Grundbildung. Skalendokumentation zur Ersterhebung bei den Lernenden. Hochschule für Heilpädagogik.

Linnehan, F. (2003). A longitudinal study of work-based, adult-youth mentoring. Journal of Vocational Behavior, 63(1), 40-54. https://doi.org/10.1016/S0001-8791(02)00012-X

Meyer, T. (2018). Von der Schule ins Erwerbsleben: Ausbildungs- und Erwerbsverläufe in der Schweiz [From school to work: Educational and employment trajectories in Switzerland]. Social Change in Switzerland. FORS.

Moser, U. (1997). Messinstrumente zu Unterricht und Leistungsbereitschaft in TIMSS+. Projektdokumentation [Instruments to measure education and achievement in TIMSS+. Project Documentation]. Amt für Bildungsforschung der Erziehungsdirektion. 
Müller, B., \& Schweri, J. (2009). Berufswechsel beim Übergang von der Lehre in den Arbeitsmarkt [Change at the transition from apprenticeship to work]. Schweizerische Zeitschrift für Bildungswissenschaften, 31(2), 199-227. https://doi.org/10.24452/sjer.31.2.5093

Nägele, C., \& Neuenschwander, M. P. (2015). Passt der Beruf zu mir [How is the fit between the occupation and myself]? In K. Häfeli, M. P. Neuenschwander \& S. Schumann (Eds.), Berufliche Passagen im Lebenslauf [Occupational transitions in the life course] (pp. 49-74). VS Verlag für Sozialwissenschaften.

Nägele, C., Neuenschwander, M. P., \& Rodcharoen, P. (2018). Higher education in Switzerland: Predictors of becoming engaged in higher vocational or higher academic education - The role of workplace factors. International Journal for Research in Vocational Education and Training, 5(4). https://doi.org/10.13152/IJRVET.5.4.2

Neuenschwander, M. P., Herzog, W., \& Holder, M. (2001). Schulkontext und Identitätsentwicklung im Jugendalter [School context and identity development in youth]. Schlussbericht. Universität Bern: Institut für Pädagogik.

Neuenschwander, M., Frey, M., \& Gasser, L. (2007). Übergang in die Sekundarstufe II und Wirkungen der Berufsbildung [Transition into upper secondary education and effects of vocational education ]. Jacobs Center for Productive Youth Development, Universität Zürich.

Neuenschwander, M. P., Hermann, M., Frank, N., \& Faschinger, S. (2013). Berufsbildungsentscheidungen beim Übergang in den Arbeitsmarkt BEN. Dokumentation des Fragebogens Lehrlings- und Personalverantwortliche [Vocational decisions at the transition into the labour market. Documentation of questionnaire for managers of vocational training and human ressoures]. Pädagogische Hochschule FHNW: Zentrum Lernen und Sozialisation.

Neuenschwander, M. P., \& Gerber, M.-S. (2014). Schulische Vorbereitung auf die berufliche Sozialisation im Lehrbetrieb [School preparation for the occupational socialisation in the training firm]. Unterrichtswissenschaft, 42(3), 244-260.

Ng, T. W. H., Eby, L. T., Sorensen, K. L., \& Feldman, D. C. (2005). Predictors of objective and subjective career success: A meta-analysis. Personnel Psychology, 58(2), 367-498. https://doi.org/10.1111/ j.1744-6570.2005.00515.x

Prümper, J., Hartmannsgruber, K., \& Frese, M. (1995). KFZA-Kurz-Fragebogen zur Arbeitsanalyse [Short questionnaire for the analysis of work]. Zeitschrift für Arbeits- und Organisationspsychologie, 39(3), 125-131. https://people.f3.htw-berlin.de/Professoren/Pruemper/instrumente/KFZASkalenkonstruktion.pdf

Roberts, B. W., Kuncel, N., Shiner, R., Caspi, A., \& Goldberg, L. (2007). The power of personality: The comparitive validity of personality traits, socioeconomic status, and cognitive ability for predicting important life outcomes. Perspectives in Psychological Science, 2(4), 313-345. https://doi. org/10.1111/j.1745-6916.2007.00047.x

Robson, K. (2010). The afterlife of NEETs. In P. Attewell \& K. S. Newman (Eds.), Growing gaps: Educational inequality around the world (pp. 185-209). Oxford University Press on Demand.

Sacchi, S., \& Meyer, T. (2016). Übergangslösungen beim Eintritt in die Schweizer Berufsbildung: Brükkenschlag oder Sackgasse [VET entry in Switzerland via "bridging solutions": Stepping stone or dead end]? Swiss Journal of Sociology, 42(1), 9-39. https://doi.org/10.1515/sjs-2016-0002

Schmid, E. (2020). Upper secondary education for youth at risk: A comparative analysis of education and training programmes in Austria, Norway, Sweden and Switzerland. International Journal for Research in Vocational Education and Training, 7(1), 21-44. https://doi.org/10.13152/IJRVET.7.1.2 
Schoon, I., \& Lyons-Amos, M. (2017). A socio-ecological model of agency: The role of psycho-social and socioeconomic resources in shaping education and employment transitions in England. Longitudinal and Life Course Studies, 8(1), 35-56. https://doi.org/10.14301/1lcs.v8i1.404

Semmer, N. K., Zapf, D., \& Dunckel, H. (1999). Instrument zur Stressbezogenen Tätigkeitsanalyse (ISTA) [Instrument for stress-related work analysis]. In H. Dunckel (Ed.), Handbuch psychologischer Arbeitsanalyseverfahren [Handbook for psychological measures of work analysis] (pp. 179205). vdf Hochschulverlag an der ETH.

Stalder, B. E. (2012). School-to-work transitions in apprenticeship-based VET systems: The Swiss approach. In S. Billett, G. Johnson, S. Thomas, C. Sim, S. Hay \& J. Ryan (Eds.), The experience of school transitions: Policies, practice and participants (pp. 123-139). Springer.

Stalder, B. E., Meyer, T., \& Hupka-Brunner, S. (2011). TREE project documentation. In M. M. Bergman, S. Hupka-Brunner, A. Keller, T. Meyer \& B. E. Stalder (Eds.), Youth transitions in Switzerland: Results from the TREE panel study (pp. 66-87). Seismo.

Stalder, B. E., \& Nägele, C. (2011). Vocational education and training in Switzerland: Organisation, development and challenges for the future. In M. M. Bergman, S. Hupka-Brunner, A. Keller, T. Meyer \& B. E. Stalder (Eds.), Youth transitions in Switzerland: Results from the TREE panel study (pp. 18-39). Seismo.

Van der Heijden, B. I. J. M., Peeters, M. C. W., Le Blanc, P. M., \& Van Breukelen, J. W. M. (2018). Job characteristics and experience as predictors of occupational turnover intention and occupational turnover in the European nursing sector. Journal of Vocational Behavior, 108, 108-120. https://doi. org/10.1016/j.jvb.2018.06.008

Volodina, A., Nagy, G., \& Köller, O. (2015). Success in the first phase of the vocational career: The role of cognitive and scholastic abilities, personality factors, and vocational interests. Journal of Vocational Behavior, 91, 11-22. https://doi.org/10.1016/j.jvb.2015.08.009

\section{Biographical Notes}

Claudia Hofmann, Dr phil., is Senior Researcher at the University of Teacher Education in Special Needs in Zurich (Switzerland). She studied psychology, media sciences and sociology at the University of Berne and worked as a career counsellor for several years. Her research interests include professional orientation, school-to-work transition for young people with disabilities and special needs, low-threshold vocational education, transition to working-live and career develompment.

Annette Krauss, M.Sc., is Junior Researcher at the University of Teacher Education in Special Needs in Zurich. She does research in developmental and health psychology, and applied vocational psychology. She is particularly interested in the prevention of mental and behavioral disorders in adolescence and works currently on her dissertation project entitled "Well-being and coping of adolescents with ADHD-symptoms and the role of various protective factors". 
Xenia Müller, Dr phil., is Senior Researcher at the University of Teacher Education in Special Needs, Zurich. After her diploma in special needs education (2003), she worked as a special teacher in several schools for children and youth with emotional and behavioural difficulties. Her main topics in research and teaching are children and youth with behavioural and emotional problems in the classroom, low-threshold vocational education and quantitative statistics.

Kurt Häfeli, Prof. Dr, studied psychology, pedagogy and social psychology at the University of Zurich, Switzerland and University of Michigan, Ann Arbor, USA. He has worked in the fields of vocational and adult education in public and private organisations and was Head of Research and at the University of Teacher Education in Special Needs in Zurich. His research interests include transition school-to-work, youth at risk, special needs education, apprenticeship, resilience, life course development, longitudinal studies. 